\title{
The Role of the NATO Support and Procurement Agency in Support to Operations
}

\author{
György GULYÁS ${ }^{1}$ - Árpád POHL ${ }^{2}$
}

\begin{abstract}
It is a basic requirement of the nations participating in multinational operations that the necessary resources be available at the required place and time, in the determined quality and quantity with optimal costs. In all of this, the Contractor Support to Operations, one of the pillars of the support to operations, has a more and more significant role. This method of support (besides the Host Nation Support) is destined for covering the gaps in the national military capabilities and capacities. It is indispensable these days to employ contractors for capitalising on their technological knowledge, as well as for achieving cost savings and a growth in the capabilities. The NATO Support and Procurement Agency (NSPA or Agency), the 'contract integrator' organisation of the NATO also support the NATO and the nations this way. In this article, the authors would like to introduce the operation of the NSPA and discuss the potential opportunities in its use.
\end{abstract}

Keywords: contracted capabilities, contract, support to operations, multinational commercial solutions

\section{Introduction}

Supporting the military operations through contracted solutions is a priority area of the logistic support. This form of the operation support is used very frequently during the peacekeeping missions, when achieving the goal makes the application of cost-effective solutions possible and when conservation of own resources is required. During the South Slavic war, the contracts came into view regarding the provision of support to the foreign troops stationed in Hungary, which also induced military researches. Endre Jávor, at Zrínyi Miklós National Defence University, defended his doctoral dissertation in 2002 with the title Logistical support activities of the host nation in a multinational peacekeeping operation, with special regard to the implementation under private law contracts. He examined the satisfaction of claims under the contracts from the point of view of the host

Instructor, University of Public Service, Faculty of Military Science and Officer Training, Department of Supply, Finance and Military Traffic; e-mail: gulyas.gyorgy@uni-nke.hu

2 PhD, Associate Professor, University of Public Service, Faculty of Military Science and Officer Training, Department of Supply, Finance and Military Traffic; e-mail: pohl.arpad@uni-nke.hu 
nation. In the dissertation he proved the need to place the support of armed forces on a national economic basis and he also defined the relationship between the contract and the order in terms of the effectiveness of the services. An important result of his research was that he determined the requirements and contexts of the services provided under private law contracts based on the experiences. ${ }^{3}$ Tibor Balla, who examined the contracting support from the point of view of the Hungarian Armed Forces further studied the topic. ${ }^{4}$

An important feature of the peace operations is that those are conducted by multinational forces often on remote battlefields (for example Afghanistan). Only a few participating nations have the capabilities to carry out all support tasks and these functions would tie up significant military forces that even forces with a resource-rich logistical support system could not afford. In the NATO, the need for common support solutions can be traced from the beginning. In 1958, the North Atlantic Council (NAC) decided to establish the NATO Maintenance Supply Services Agency (NMSSA), whose responsibility at that time was limited to three major weapon systems. ${ }^{5}$

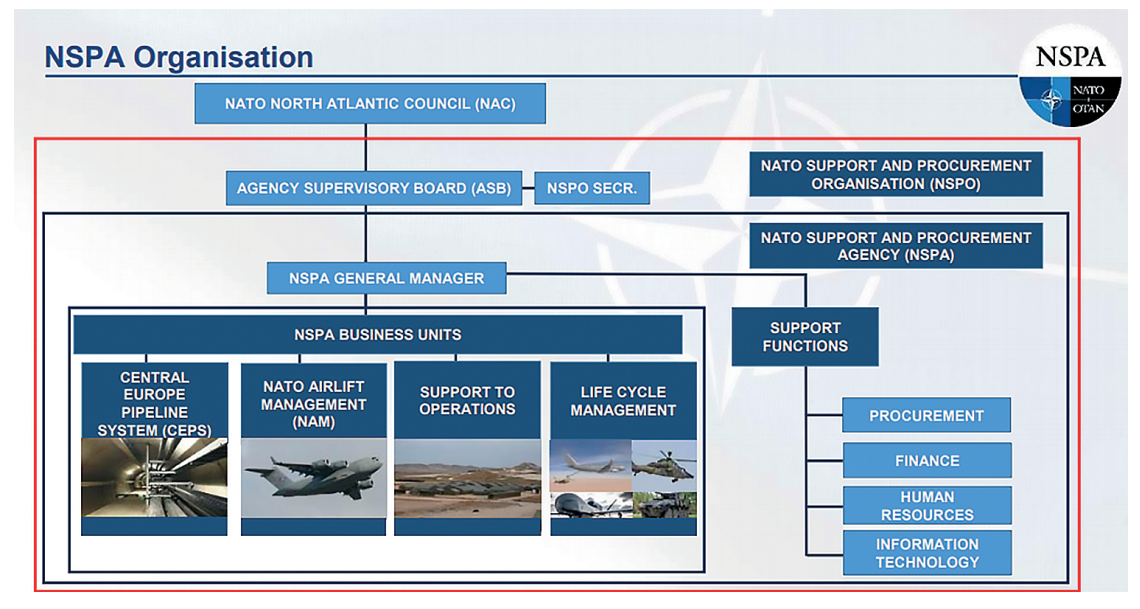

Figure 1: NSPA organisational structure

Source: NSPA/OLSP Basic Overview and Benefits (Agenda Item VIII), Presentation by Mr Dane Tynes, 23 ${ }^{\text {rd }}$ OLSP Committee Meeting, 20 October 2020.

The multinational logistics support solutions have gained ground and their effectiveness have been proven. According to the AJP-4(B), the NATO Agencies can support the military operations based on their competence.

3 Endre Jávor, A befogadó ország logisztikai támogató tevékenysége többnemzetiségű békefenntartó hadműveletben, különös tekintettel a magánjogi szerződések alapján történő végrehajtásra [Logistical support activities of the host nation in a multinational peacekeeping operation, with special regard to the implementation under private law contracts] (PhD dissertation, Budapest: Miklós Zrínyi National Defence University, 2002).

4 Tibor Balla, Civil és katonai javak a szerződött logisztikai szolgáltatások tükrében [Civilian and military goods in the light of the contracted logistical services] (PhD dissertation, Budapest: Miklós Zrínyi National Defence University, 2004).

5 Ibid. 
The NATO Support and Procurement Organisation (NSPO) is established as a subordinate legal body of the North Atlantic Council (NAC). NSPO includes the Agency Supervisory Board (ASB) which is the governing body of the NSPA and all NATO nations are represented in it.

The mission of the NSPO is to provide responsive, effective and cost-efficient acquisition, including armaments procurement, logistics, operational and systems support and services to the Allies, NATO Military Authorities and partner nations, individually and collectively, in time of peace, crisis and war, in order to maximise the ability and flexibility of their armed forces, contingents, and other relevant organisations, within the guidance provided by the North Atlantic Council (NAC), to execute their core missions. The NSPO's executing body is the NATO Support and Procurement Agency.

In other words, NSPA is at the service of the NATO members and partner nations, equipment procurement and life cycle management, logistics services provider. The Agency is a 'no profit, no loss' organisation, without aiming the profit, covering the overheads, salaries and operational costs by the administrative fees of the established and managed contracted capabilities. The Agency is Customer Funded, Governed by the Agency Supervisory Board. It acts as an extension of the Armed Forces, covering the capability gaps missing from the military or national defence industry capabilities and capacities, but the NSPA does not compete with those.

\section{The basic procurement activity of the Agency}

A main objective of the NSPA is to obtain, through international competitive bidding, the most economical prices for materiel and services. The most economical proposal, which meets the technical and contractual requirements defined in the Request for Proposal (RFP), will normally be accepted.

To collect potential service providers, the NSPA uses a source file that includes commercial companies from the industry. The main purpose of the source file is to assist and facilitate the realisation of an effective source selection process making possible a successful competitive procurement.

NSPA normally acquires the materiel, supplies and services, required by its customers, through the international competitive bidding process from commercial sources. The procurement policy of the NSPA is based on the principles of integrity, transparency and equal treatment. However, under some very specific circumstances, the solicitation procedures can differ from the full and open international competitive bidding process. These circumstances are the following:

1. Sole Source: In case of existing only one known source which is capable of providing the required materiel, supplies and/or service.

2. Single Source: The procurement circumstances, as listed below, may justify the need to take into consideration only one source during the solicitation process, although other potential sources may also exist. 
3. Urgency: These conditions can come into consideration when application of the full competitive bidding process would cause a delay in delivering the required materiel or services, defined by the customer as emergency requirements.

4. Low Value: When the extended contract value in question is below the NSPA Financial Level A (10,000 EUR in 2021).

5. Security: When the security requirements prohibit or restrict the distribution of the RFP data.

6. Commonality of Equipment: When the customer, for training, maintenance or other interoperability reasons, requests that the equipment to be procured must be from the same source as the equipment already in its inventory. ${ }^{6}$

\section{Some standard types of contractual instruments}

Depending on the specific terms required, the following standard types of contractual instruments shall be utilised exclusively:

Fixed-Price Contracts: The significance of these contracts is that they provide for the procurement of materiel and/or services at a fixed unit price. This type of contract assets should be utilised unless another type would be more appropriate.

Outline Agreements: Outline agreements set up the specifications, the nature and price of deliverables or the method by which they are to be determined; also, they determine the value and/or quantity of the goods or services.

Outline agreements are executed by purchase orders, issued successively, as needed. Each individual purchase order defines the goods and services that are required, described in the outline agreement, furthermore, determines the necessary quantity.

If, for duly substantiated reasons, it is impossible for a single company to cover all shipments under the most favourable conditions or for a guaranteed reserve, outline agreements for the same shipments may be concluded with several contractors, provided that the agreements expressly specify the conditions under which purchase order may be issued to the various contractors concerned.

Basic Contractual Instruments: The Basic Contractual Instruments (BCIs) set out the negotiated contract term that will apply to future purchases made during the term of the BCI. BCIs can be used when past experience and future plans show that a significant number of separate contracts can be entered into with a contractor during the BCI period and significant recurring negotiation problems arise with a particular contractor. BCIs do not oblige NSPA to place orders or contracts with the contractor. ${ }^{7}$

6 OI 4200-01 NSPA Procurement Operating Instructions, NATO Support and Procurement Agency, 18 March 2019.

7 OI 4200-01 NSPA Procurement Operating Instructions, NATO Support and Procurement Agency, 18 March 2019. 


\section{Establishing commercial contracted capabilities}

When establishing a new commercial contracted capability the time required to develop the capability is key. There are different facts and factors that influence this time period and the Agency also works on different practices how to shorten it.

Based on many years of experience, it is proven that the establishment of a new contracted capability, supporting the nations operations, requires approximately 6 months. It is the default practice, when the Agency conducts an international competitive bidding process, calling the capable service providers NATO-wide, from the NSPA Source File. These 6 months starts with the receipt of the requirement and ends with the signed, established contract. (When Single or Sole Source procedure is justified the lead-time is shorter, due to the fact that NSPA needs to conduct the solicitation process with the involvement of only one potential service provider.)

A significant part of the 6 months lead-time is dedicated always to assistance to the customer in developing and, if necessary, amending the Statement of Requirement (SOR). Based on this document, NSPA develops the Statement of Work (SOW), which is the basic document of the RFP process. To shorten the 6 months lead-time, the Agency developed some so-called "SOW+", in the frame of a kind of contingency planning. Actually, these were pre-planned Statement of Works for the most probable service requirements, which included a kind of template requirement and statements. For example, to support operations, there are SOWs+ for potential base services, food and fuel supply and service requirements, and so on. In case of a firm requirement, these products have been updated and adjusted to the real requirement.

The Basic Contractual Instruments (BCIs) provide a more effective solution in supporting operations. In this case, the NSPA does not conduct a full international competitive bidding cycle but only pre-select the most competent potential service providers. With pre-selecting the potential service providers, a significant part of the solicitation process can be left out later, when the actual task arrives at the Agency. In addition, at this time, NSPA can generate a mini competition between the pre-selected BCI holders. (NSPA provides services through different BCIs, one of them is the Strategic Aeromedical Evacuation Services with two air transport BCI holder companies. This capability provides the services for 5 years based on the valid BCI.)

However, if the Customers need contracted capabilities with (very) short notice time, those capabilities must be ensured in advance through pre-established Assured Access Contracts or dormant contracts. It means that the contracted capabilities have already been established, the necessary assets, supplies, with the associated transport capacity - if required - have been put aside for the customer by the service provider company, but the contract will be activated only if needed. (Recently, assured access contracts are applied by nations that assume tasks in multinational formations with their units in very high readiness, like the Very High Readiness Joint Task Force (VJTF), since neither the NSPA nor any contractors can develop a new contracted capability within a few days to meet the customer's requirement.)

NSPA hosts 32 Support Partnerships (SP). Nations, using the same weapon systems or are interested in utilising the same services, can establish new SPs to share the 
costs, knowledge, experience, also to form and use an asset pool. Two nations suffice to form a new SP and the NSPA support those SPs through the SP Offices manned by the Agency. Each SP is governed by its own Committee (formed by the representatives of the participating nations) and the SPs have their own agreed legal framework. The member nations decide the budget, decide and prioritise the new projects and agree the associated manpower provided by the dedicated SP Office of the NSPA.

Approximately 80 per cent of the requirements arrive to the Agency through SPs. In this case, the customers need to send a simple Tasking Letter and the Statement of Requirement to the given Support Partnership Office to start the process, aiming the development of a new commercial contracted capability. The other basic way of starting the process, is signing a Sales Agreement between the customer nation and the Agency. Since in the latter case the legal questions have not been agreed yet, setting those questions also require some time, extending the period necessary to establish the new contracted capability. Sales Agreement is required if the customer is not a member of the SP which is expected to establish the contracted capability.

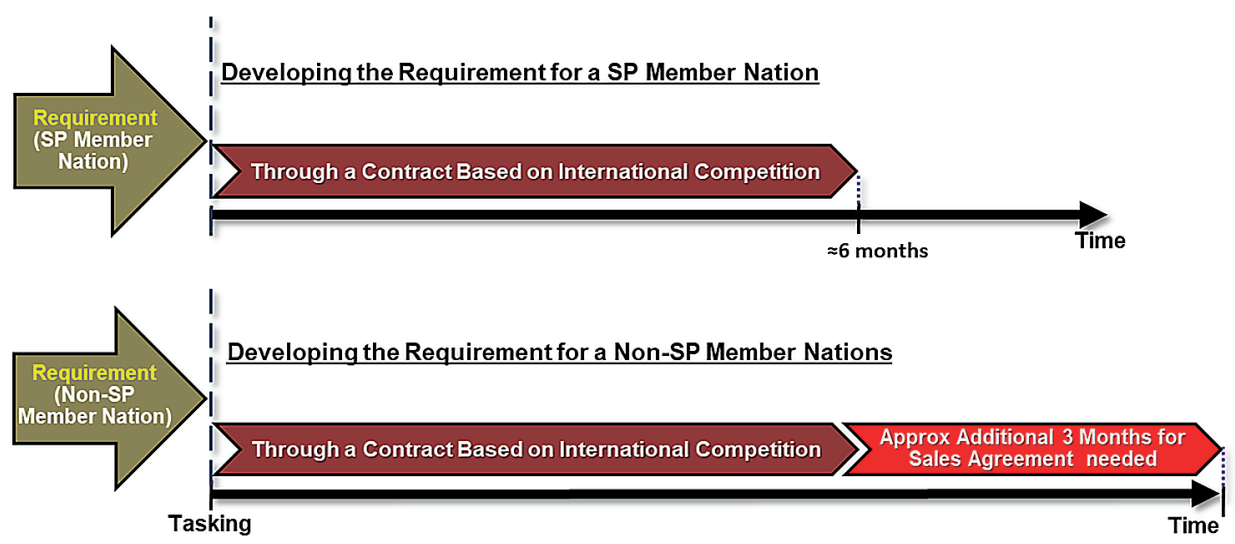

Figure 2: The basic lead-time of establishing contracted capabilities for supporting operations

Source: Compiled by the author.

If the customer decides to join already established, ongoing contracted capabilities, the lead-time the NSPA to sign a contract with the contractor, on behalf of the customer, and to start the provision of services is much shorter.

\section{In the area of Support to Operations and Exercises}

Today the Agency is organised around the support partnerships and programmes. Recently, the geopolitical situation is changing rapidly. Developments in the Eastern part of Europe, the Middle East and Northern Africa spurred the NATP to change its priorities. Besides 
the continuation of the current missions in Afghanistan and Kosovo, new priorities show up on the horizon.

The strategic aim of the NSPA is to provide comprehensive support to the operations, with a special attention to Deterrence and Defence (see later). This requires the Agency to engage early in planning and decision making to respond quickly to emerging requirements. The Contract Integrator capability of the Agency is key to link NSPA to NATO's operational planners. In accordance with that, the Agency has the necessary managerial capability to engage with the leadership in the Allied Command Operations and the nations. NSPA keeps it very important to strengthen and improve existing capabilities, like: fuel, transport and infrastructure. The recent greater emphasis on exercises and interoperability increases demand in this domain. All things considered, the main effort of the Agency is recently to improve the operational responsiveness.

Support to operations area requires a continued attention. The key focus is the need to provide support for Deterrence and Defence related missions and exercises. Expanding the Operational Logistics Support Partnership (OLSP) and the very proactive approach to fuel support for the VJTF is also considered. Other associated NATO operational policies underlined included Contractor Support to Operations and collective contracting including Rapidly Useable Enabling Contracts (RUECs).

The Agency's mission and vision have been updated according to the aforementioned. In particular, 'responsiveness' will be a key factor to ensure that NSPA is able to overcome the upcoming challenges. ${ }^{8}$

\section{New challenges in the supply chain and support to operations}

The developments in the Crimea and in East Ukraine in 2014 spurred the NATO to develop and implement new and adequate defence concepts. The new security challenges near the eastern flank of NATO are reflected in the decisions and declarations of the NATO Wales (2014) and Warsaw Summit (2016) when a group of actions and concepts have been articulated to 'deter' any aggression and to provide 'defence' to Europe (Deterrence \& Defence or in short: D\&D).

The focus shifted from the expeditionary operations to Europe again, new or amended NATO forces, entities, missions were created (like the enhanced NATO Reaction Force (eNRF), NATO Force Integration Units (NFIUs), enhanced Forward Presence (eFP) and so on) with new defence concepts (that is, Graduated Response Plans (GRPs,) creating and applying the VJTF, and so on). The new concepts had a huge impact on the new requirements for contracted capabilities and required a new approach to support to operations from the NSPA, too.

It became clear that in some cases the industry is not responsive enough and cannot satisfy the new requirements, mainly those with very short notice time or the surge requirements. NATO had to re-define the military requirements, re-assess the existing military and industrial capabilities and capacities, including the available and necessary

8 Appendix 2 - NSPA Strategic Direction 2018 - 2022 Lines of Development, NSPA Annual Report 2019. 
infrastructure, and understand again the operations and practices of the defence industry in Europe.

The multinational cooperation among the NATO member nations, the time factor and the significance of available sources came to the front, and the responsiveness, flexibility and scalability of contracted capabilities got a much higher emphasis.

To fill the forces of the eNRF (and the eFP) annually, the NATO conducts Force Generation conferences when the nations offer their units to NATO through a bidding process. Each year, a willing nation assumes responsibility, as framework nation, for the VJTF, which is an element of the eNRF. Framework nations are volunteered in advance, this way, the units are in a pre-defined rotation that makes possible for the nations to plan the sources of their logistics support ahead. Although the required units are available in the eNRF, their rapid deployment to the east, to secure the eastern flank of NATO, also their sustainment still remained a challenge in some cases (that is, quick deployment of heavy equipment, fuel supply independent of Russian sources, and so on).

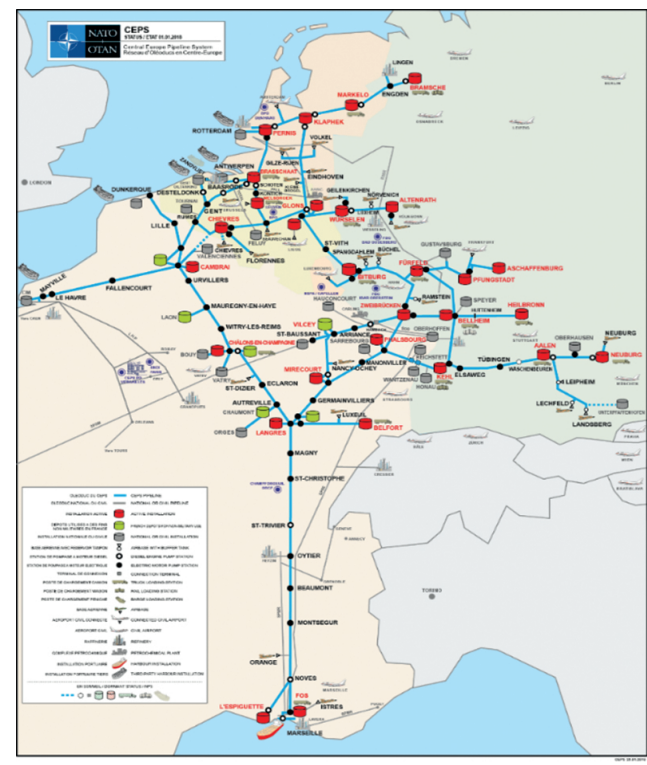

\section{The layout of the Central Europe Pipeline System}

The Central Europe Pipeline System (CEPS) Programme (NSPA): manages the operation, financing and maintenance of an integrated, cross-border fuel pipeline and storage system in support of NATO's operational military requirements during peacetime, crisis and conflicts, including expeditionary operations.

Operations run on a 24/7 basis, with the NSPA CEPS Programme Office serving as the liaison between National Organisations and NATO authorities.

Figure 3: The layout of the Central Europe Pipeline System

Source: NSPA/OLSP Basic Overview and Benefits (Agenda Item VIII), Presentation by Mr Dane Tynes, 23 ${ }^{\text {rd }}$ OLSP Committee Meeting, 20 October 2020.

In the era of the Warsaw Pact, NATO possessed a very reliable logistics supply chain in Western and Central Europe and the responsibilities were also very well outlined. Due to the collapse of the Warsaw Pact, then with the main operations in the Middle East, the security questions in Europe and the previously strictly maintained logistic capabilities and capacities got only a secondary significance. It was the time when the European Ministries of Defence started to outsource some of their tasks and downsize the military 
units. Some military capabilities, as well as the civilian capacities, dedicated to military use, were left degrading.

The developments in Ukraine in 2014 found NATO in the above detailed environment making the situation more complex, that is, the remaining reduced capabilities and capacities had to cover double as much geographical area as the territory of the NATO member nations was at the end of the 1980s (the Central Europe Pipeline System was established in 1959 to deliver fuel for military air and ground vehicles in Belgium, France, the Netherlands, Luxembourg and Germany, which country was the eastern flank of NATO until the end of the 1990s). ${ }^{9}$

\section{Potential responses to the challenges through multinational solutions}

Due to the new challenges and requirements, the new contracted capabilities have to be flexible and responsive enough to be able to satisfy the military requirements. But how is the D\&D sustained currently?

The characteristics are the following:

1. Several Graduated Response Plans established for only one set of NATO forces (which are the units of the eNRF)

2. Large scale strategic movements to and within Europe

3. Annual rotation of forces or elements and rolling sustainment requirements

4. Not clear and firm operational requirements (NATO plans cover limited capabilities)

5. Many multinational formations even below battalion level

6. Limited standing Host Nation Support (HNS) related arrangements (however, there are rolling requirements - like for fuel and food - and high expectations of potential HNS)

7. Higher and higher dependency on commercial support to operations

8. National yearly (one-off) fixed contracts (which expire at the end of the year and a new one has to be established by the beginning of the next year for another nation that is, for the next VJTF Framework Nation in the rotation plan)

NSPA is the NATO Contract Integrator organisation, which possesses all the capabilities that are necessary for the effective support to nations through contracted capabilities (legal arrangements, common procurement rules, international competitive bidding process, contractual arrangements in one integrated system). NSPA is also capable of receiving/ collecting and consolidating requirements so that later it can step up the market with one single requirement representing all the customers. The previously mentioned SPs, within the NSPA, provide perfect platform to the SP member nations for building consensus for multinational commercial solutions. Regarding satisfying the D\&D requirements, establishing multinational contracted capabilities is very reasonable since we speak about rolling and recurring supply and service requirements (that is, fuel, food, road/rail

$9 \quad$ NSPA official website, Central Europe Pipeline System. 
transportation, base services) which are necessary for the different nations' units for their annual rotation (VJTF).

NSPA also had to take into consideration the different characteristics of nations, in other words, nations have different resource allocations, levels of ambition, legal requirements and limitations. Besides the nations' requirements, NSPA had to study the current resources of the market and work out such contracted capabilities which are attractive enough to the market and which covers its interests, as well (that is, multi-year contracted capabilities which are fully utilised).

An already existing SP can provide the platform for the development of a new multinational contracted capability. The member nations of a SP can capitalise of the inherent advantages of the SP (that is, the already existing legal framework and agreed operating mechanism, the shared experience and expertise, and so on).

It is also feasible for the nations under the umbrella of an already existing SP to establish sub-groups for special tasks, so called Project Groups.

\section{The Project Group concept}

What does Project Group (PG) mean? In the NSPA we can find examples of functioning PGs under Support Partnerships. Two of them work under the Operational Logistics Support Partnership (OLSP). OLSP is a SP fully dedicated to support to operations. The OLSP has 26 member nations currently and provides support to the member nations through its 4 pillars:

1. Standing legal framework for members to access NSPA services (no need any sales agreements, a simple Tasking Letter is required in the agreed and OLSP Committee approved form)

2. Conducts planning with member nations and project development within NSPA (during the project development, OLSP cooperates with specialised NSPA Program Offices and Divisions - PODs, that is, Fuel or Food Branches, Transportation and Warehousing Division)

3. Provides National and NATO Exercises training and education support related to commercial solutions for military operations

4. Facilitates, innovates and develops multinational commercial solutions ${ }^{10}$

The OLSP Support Partnership Committee makes OLSP possible to establish PGs. A PG is formed by those OLSP member nations that use the given service and the PG gives the governance of the service. The basic frame of the service is the OLSP legal framework. The PG makes decisions on the operation of the subject service, decides the rules of the operations, the budget and the NSPA personnel associated to support the management and execution of the services. The first PG was established in 2019 for the Global Food Services. The success of the Global Food Services has already been proven, providing food

10 NSPA/OLSP Basic Overview and Benefits (Agenda Item VIII), Presentation by Mr Dane Tynes, 23 ${ }^{\text {rd }}$ OLSP Committee Meeting, 20 October 2020. 
supply and services currently to the Netherlands, Italy and the United States in Europe and in the Middle East.

Some of the OLSP member nations have already realised the advantages of the PGs and articulated clearly in the SP Committee Meetings or individually to the SP Office that more and more multinational framework contracts are needed under SPs providing support to operations. If so, OLSP found it feasible to offer governance and management option under the existing, well-functioning and responsive partnership. Furthermore, capitalising on the experiences of the already existing Global Food Services Project Group would make it possible to re-award the success of that PG, saving costs, time and additional efforts for the nations.

Responsibilities of the member nations in a PG: The PG steers the given service. The member nations fund the service and participate in the PG meetings, deciding on future activities and objectives. The PG assigns specific tasks to be performed within the context of the given service and the objectives of the specific PG. Furthermore, the PG forecasts and approves the program of work for the service, inclusive of future projects and potential support requirements. The program of work provides transparency for forthcoming requirements and helps to prioritise the use of services and the NSPA workforce. Each member nation of the PG provides a national official representative.

Responsibilities of the NSPA SP Office: The NSPA SP Office is the administrative entity that provides oversight and coordination for all project activities. The SP Office coordinates the PG meetings and reports the PG member nations.

In the NSPA comprehensive concept to sustain the D\&D related requirements of the nations the most properly, the Project Group concept is only one element.

Beyond the challenges in supporting the D\&D related requirements, described in section New challenges in the supply chain and support to operations, NSPA had to consider all the factors which may cause a potential risk to the establishment and provision of seamless contracted services to the nations. These factors can be:

1. too high cost of services

2. too long lead-time to start the services

3. lack of capable service providers or dominant non-NATO country (that is Russian) ownership over sources and facilities (that is, fuel sources and facilities in Eastern Europe)

4. reluctance of the market to answer the nations' call, because of non-doable requirements or economy of scale

5. non-compliance or late delivery by the service provider or interruption of services

6. too rigid frames of existing contracted capabilities which reduces the opportunity to be used by additional nations, the contract to be scalable

NSPA had to address those risks, too. 


\section{Creative Defence Contracting}

Due to the new D\&D concepts, using military units provided by rotating framework nations, the nations stepped up with more and more requirements for support to operations. To overcome the factors, mentioned in section The Project Group concept, which may pose risks to the establishment of contracted capabilities, and to find the contracted solutions, which are equally favourable to both the nations and the market, NSPA had to think of contracting procedures and principles through a new and creative lens. NSPA realised that the defence concept related timelines have to drive the characteristics of the contracted capabilities. Furthermore, to be able to satisfy different national requirements, NSPA had to consider the different national resource allocations, the national legal requirements and limitations, as well as the different national levels of ambition. Also, the new contracted capabilities should satisfy the short noticed and recurring requirements thereby avoiding repetitive commercial procurement procedures every time when a new operational support requirement arrives. All of this entailed the creation of new contracting approach and principles.

The new support to operations requirements can be satisfied through standing, scalable, adaptable and flexible contracted capabilities, which are available to all nations and can provide contracted services to the rotations of different military units, as well. The services, collected in packages or modules, make possible the national or multinational requirements to be served from a 'menu' that takes into account the special national needs. Based on the aforementioned, the Creative Defence Contracting Principles that have to be considered and applied are:

1. contracted capability with modularity and scalability

2. long term contracted capability, 3 years or more (usable by eNRF, VJTF, HNS, eFP)

3. indefinite delivery and quantity element

4. adaptable and flexible

5. economies of scale

6. responsiveness against readiness requirements

7. satisfying recurring and rolling requirements

8. applying the multinational Project Group concept

9. applying payback mechanism ${ }^{11}$

\section{Example of the new type of multinational contracted capability}

\section{The OLSP Global Food Services}

The Global Food Services (GFS) is a NSPA standing and global capability with scalable and turnkey food services for nations deployed abroad or on exercises. The services are under the OLSP umbrella and governed by the Global Food Services Project Group (GFS PG). The establishment of the contracted capability is sponsored by the Netherlands, which is the only PG member currently. The capability is accessible to all nations. GFS comprises of three capability

11 György Gulyás, Synopsis of the Final Report for the Multinational Rail Transport Services Feasibility Study, Agenda Item XII, Presentation, 23 ${ }^{\text {rd }}$ OLSP Committee Meeting, 20 October 2020. 
packages or modules: Food Supply (only supplies without any services), Human Resources (performing catering, storing, cooking or other food related services) and Catering Operations. The capabilities are scalable in order to meet the requirements of all nations. It is a global capability with the main focus areas in Europe, Africa and the Middle East. The services can be delivered within 90 days of the received requirement.

The GFS contract was awarded on 1 March 2019. The contract mechanism is a hybrid solution, which is a Basic Contractual Instrument (BCI) where outline agreements have been awarded to multiple service providers. A total of four commercial companies hold outline agreements across the three GFS capability packages. The contract call-offs are executed in accordance with the customer requirements, so nations use only the package which fits best to the given military task or mission to be supported. Due to the contract volume, the scope and scale, as well as to maintain competitive advantage, each call-off is based on dual source as a minimum.

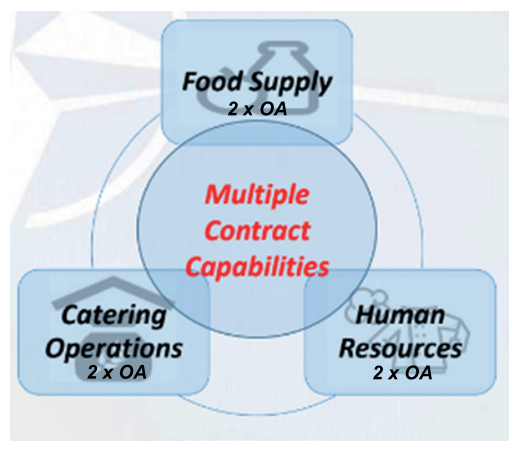

Within the Catering Operations food, bottled water and catering services can be found, including an option for a stand-by capability (or a dormant element of the package) supporting the units in very high readiness.

Figure 4: The Capability Packages of the Global Food Services

Source: Julien Goreing, OLSP Global Food Services, Agenda Item XIII, Presentation, $23^{\text {rd }}$ OLSP Committee Meeting, 20 October 2020.

This call-off process makes possible for the NSPA to chose the best offer from the service providers for each requirement, maintaining competitiveness, as well as permanent optional sources.

NSPA/OLSP encourages the nations to join the GFS PG. This way they can decide on the future projects of the services and can have an influence in governing the services. Although the costs of maintaining the GFS (that is, the salary of the OLSP Office associates dedicated to the support of the GFS) is paid by the GFS PG member nation(s), OLSP worked out a payback mechanism: the non-PG member nations have to pay a fee, furthermore, non-OLSP member nations pay usage fee and surcharge when they use the services (GFS fees and surcharges levied in accordance with NSPO Directive No. 3999 and approved during the $19^{\text {th }}$ OLSP Committee Meeting). The fees and surcharges offset the administrative (GFS related overheads, like salaries) and operational costs (actual cost of a service) of the PG member(s). ${ }^{12}$

12 Julien Goreing, OLSP Global Food Services, Agenda Item XIII, Presentation, 23 ${ }^{\text {rd }}$ OLSP Committee Meeting, 20 October 2020. 


\section{Summary}

The above new type contracted capability brought a lot of benefits to the customer nations. Naturally, there were (and exist) many other multinational contracted capabilities offered by different Program Offices or Divisions of the NSPA (that is, the Global Access Services, which provides worldwide provision of plane refuelling services) but the GFS was the first one which was established with such a comprehensive approach addressing the new type of requirements. These types of capabilities are able to support requirements with a 'normal' lead-time but also very short-noticed ones for units in very high readiness. The services are available in peacetime, crisis and war worldwide.

Their basic benefits are among others:

1. Standing capability with established governance (Project Group) and Terms of Reference under a standing Support Partnership - no need for a Sales Agreement, no need to develop a specific SOW when sending the requirement to the NSPA

2. The standing capabilities have been established with high value for future scalability, services are open to all nations (including non-Project Group member and nonSupport Partnership member countries)

3. The sponsoring nation funds the cost of manpower to maintain the capability within the Project Group - but offset through fees and surcharges

4. The contracted capability packages/modules are in place with outline agreement holders - no need for a protracted competitive bidding process only a 'mini competition' among the outline agreement holders, when an exact task arrives at the NSPA for the services

5. Achieved reduced lead-time from tasking to contracting - from 6 months to 90 days

6. The capability packages/modules function like a 'menu' - nations can chose the proper one which fits the best to their military mission, budget and other national characteristics

7. The services can properly satisfy the annual rotation of force elements (that is, VJTF framework nations) and also the rolling sustainment requirements

With this type of multinational contracted solution, applying the PG concept, the nations are heavily involved in the decision making process, deciding what future projects should be launched next, what budget shell be used, always keeping in mind their national interests. NSPA can re-award the success of this contracted capability with establishing new ones, depending on the nations' interests, to cover the most demanded services that can come into question in case of operations. The establishment of the Global Fuel Services contracted capability is nearing its end (sponsor - and PG member nation - is the Netherlands) and the development of the Global Base Services capability starts recently (sponsor is the United States) applying the PG concept in both cases.

The NSPA developed a new generation of the multinational contracted solutions with new contracting technics and new governing concept. Now the nations should decide what additional capabilities should be established taking into account their national interests and assessing where their requirements can fit in the new capabilities. Or, in another way, how those current and future capabilities could best serve their national or multinational 
military missions. In a direct or indirect way, the new contracted capabilities serve effectively the collective NATO defence efforts, as well.

\section{References}

AJP-4(B) Allied Joint Logistics Doctrine. Online: https://assets.publishing.services.gov.uk/ government/uploads/attachment_data/file/907825/doctrine_nato_logistics_ajp_4.pdf Appendix 2 - NSPA Strategic Direction 2018 - 2022 Lines of Development,

NSPA Annual Report 2019. Online: www.nspa.nato.int/resources/site1/General/publications/ NSPA_Annual_Report_2019_e.pdf

Balla, Tibor, Civil és katonai javak a szerződött logisztikai szolgáltatások tükrében [Civilian and military goods in the light of the contracted logistical services]. PhD dissertation, Budapest: Miklós Zrínyi National Defence University, 2004. Online:

www.uni-nke.hu/document/uni-nke-hu/balla_tibor.pdf

Goreing, Julien, OLSP Global Food Services, Agenda Item XIII, Presentation, 23 ${ }^{\text {rd }}$ OLSP Committee Meeting, 20 October 2020. Online: https://eportal.nspa.nato.int/public/eportal. aspx

Gulyás, György, Synopsis of the Final Report for the Multinational Rail Transport Services Feasibility Study, Agenda Item XII, Presentation, 23 ${ }^{\text {rd }}$ OLSP Committee Meeting, 20 October 2020. Online: https://eportal.nspa.nato.int/public/eportal.aspx

Jávor, Endre, A befogadó ország logisztikai támogató tevékenysége többnemzetiségú békefenntartó hadműveletben, különös tekintettel a magánjogi szerződések alapján történő végrehajtásra [Logistical support activities of the host nation in a multinational peacekeeping operation, with special regard to the implementation under private law contracts]. PhD dissertation, Budapest: Miklós Zrínyi National Defence University, 2002. Online: http://ludita.uni.nke.hu/repozitorium/bitstream/handle/11410/8961/ Tartalomjegyz\%c3\%a9k\%21?sequence=1\&isAllowed=y

NSPA official website, www.nspa.nato.int/about/history

NSPA official website, Central Europe Pipeline System, www.nspa.nato.int/about/ceps

NSPA/OLSP Basic Overview and Benefits (Agenda Item VIII), Presentation by Mr Dane Tynes, 23 $3^{\text {rd }}$ OLSP Committee Meeting, 20 October 2020. Online: https://eportal.nspa.nato.int/public/ eportal.aspx

OI 4200-01 NSPA Procurement Operating Instructions, NATO Support and Procurement Agency, 18 March 2019. Online www.nspa.nato.int/resources/site1/General/business/procurement/ General\%20info/OI-4200-01-EN.pdf

OI 4200-01 NSPA Procurement Operating Instructions, NATO Support and Procurement Agency, 18 March 2019. Online: www.nspa.nato.int/resources/site1/General/business/procurement/ General\%20info/OI-4200-01-EN.pdf 